\title{
Light and electron microscopical observations on the male excurrent duct system of the common shrew (Sorex araneus)
}

\author{
Fumie Suzuki and P. A. Racey* \\ Department of Anatomy, School of Medicine, Chiba University, Chiba 280, Japan, and \\ * Department of Zoology, University of Aberdeen, Aberdeen AB9 2TN, U.K.
}

\begin{abstract}
Summary. In sexually active common shrews (Sorex araneus) the rete testis is a simple sac-like structure situated superficially between the equator and the anterior pole of the testis, and its epithelium contains glycogen-rich cells. In the ductuli efferentes, the tight junctions of the epithelial cells are poorly developed. The epididymis can be divided cytologically into initial, middle and terminal segments, and some variations are apparent in the fine structure of the principal cells throughout the duct. In the initial segment and in the most proximal part of the middle segment, mitochondrion-rich cells occur sporadically in the epithelium. The ductus deferens is divided into three anatomical regions, a tortuous pars epididymica, a straight middle portion, and an ampullary region. The distal half of the straight portion is distended, and appears to function, together with the terminal segment of the epididymis, as a sperm reservoir.
\end{abstract}

\section{Introduction}

Shrews belong to the most conservative order of eutherian mammals, the insectivores (Eisenberg, 1981). The anatomy of the male excurrent duct system has been briefly described by Brambell (1935) and by Pearson (1944) but histological study has been limited to only two portions of the ductus deferens (Ärnbäck-Christie-Linde, 1907). A detailed description of the morphology of the excurrent duct system as seen in tissue prepared using modern techniques is lacking.

Many workers have examined the regional differentiation and species variations of the excurrent duct. For example, in the epididymis, Nicander $(1957,1958)$ and Reid \& Cleland (1957) have demonstrated 8 different regions and, more recently, Glover \& Nicander (1971) have suggested that histologically, cytologically and functionally the epididymis should be divided into three main regions: initial, middle and terminal segments, the first two of which are concerned with sperm maturation and the last is the sperm store. However, the extent to which these terms are applicable to all mammalian epididymides has yet to be established as has the functional significance of variations in the ductus deferens (Hamilton \& Cooper, 1978; Ramos, 1979).

We have previously examined the epididymis of the European mole, Talpa europaea (Suzuki \& Racey, 1976). To extend our observations on insectivores, we examine here the excurrent duct system of the male shrew, and compare it with that of other mammals.

\section{Materials and Methods}

Seven mature male shrews (Sorex araneus) were caught in Longworth live traps in the vicinity of Aberdeen, Scotland, or taken from a laboratory breeding colony, during the sexually active season, 
May-September. Immediately after death, the testes and the excurrent duct systems were fixed in $2.5 \%$ glutaraldehyde and $1 \%$ paraformaldehyde in either $0.05 \mathrm{M}$-cacodylate or -phosphate buffer at $\mathrm{pH} \mathrm{7.4.} \mathrm{Four} \mathrm{individuals} \mathrm{were} \mathrm{fixed} \mathrm{by} \mathrm{intravascular} \mathrm{perfusion} \mathrm{through} \mathrm{the} \mathrm{thoracic} \mathrm{aorta} \mathrm{with} \mathrm{the}$ same fixative. For light microscopy, the organs were separated into four blocks: testis, the proximal and the distal parts of the epididymis, and the ductus deferens with the ampulla. The blocks were dehydrated with a graded series of ethanol solutions and embedded in glycol methacrylate resin. Sections cut with glass knives were stained with toluidine blue. For transmission electron microscopy, small blocks of tissue were taken from the rete testis, ductuli efferentes, and several different points of the epididymis. They were post-fixed for $1 \mathrm{~h}$ with $1 \%$ osmium tetroxide buffered with cacodylate, and were dehydrated with a graded series of ethanol solutions before they were treated with $0.1 \%$ uranyl acetate in $95 \%$ ethanol for $20 \mathrm{~min}$. After completion of dehydration and treatment with propylene oxide, they were embedded in Epon 812. Thin sections were cut with a diamond knife and stained with $2 \%$ uranyl acetate followed by lead citrate. They were observed with an Hitachi HU-11DS electron microscope at $75 \mathrm{kV}$. For freeze-fracture, small blocks of tissue were taken from the ductuli efferentes and middle portion of the caput epididymidis (at III in Textfig. 1), and were treated with buffered $30 \%$ glycerol for $3 \mathrm{~h}$. The tissue blocks were then placed on a copper plate with wells and frozen with liquid Freon 22 and liquid nitrogen. The specimens were fractured and replicated in a brass block-type apparatus (Hitachi, HFZ-1) at $1.33 \times 10^{-4} \mathrm{~Pa}$ at $-115^{\circ} \mathrm{C}$. Pure platinum and carbon were used for shadowing and backing respectively. The replicas were cleaned of adhering tissues in sodium hypochlorite for $1 \mathrm{~h}$ and then washed with water. The cleaned replicas were collected on carbon membrane mounted on 200-mesh copper grids.

\section{Observations}

The gross anatomical view of the male reproductive organs is shown in Text-fig. 1 and Pl. 1, Fig. 1.

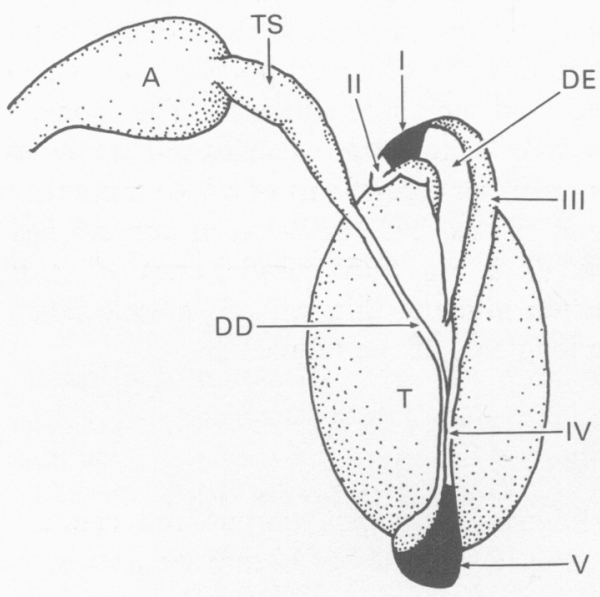

Text-fig. 1. A diagrammatic representation of the dorsal aspect of the right testis and epididymis of the sexually active shrew. Roman numerals (I-V) in the epididymis show the position of tissue collection for Text-fig. 2. The black areas marked I and V represent initial and terminal segments respectively, and the area lying between these two segments is the middle segment. T, testis; DE, ductuli efferentes which arise from the rete just above the equator of the testis; DD, ductus deferens; TS, terminal swelling of ductus deferens; A, ampulla. 


\section{Juncture between seminiferous tubules and rete testis}

The seminiferous tubule tapers sharply as it terminates, and the lining epithelium of the terminal portion consists almost exclusively of Sertoli cells. The terminal segment of the seminiferous tubule and the rete testis are joined with a short transitional tubule, with a low columnar lining epithelium. The transition between the epithelium of the Sertoli cells to this low columnar epithelium is abrupt. The junctional area between the seminiferous tubules and the rete testis is surrounded by a mass of Leydig cells (Pl. 1, Fig. 2).

\section{Rete testis}

The rete testis of the shrew is situated superficially between the equator and the upper pole of the testis, and does not extend deeply into the testis. The rete testis is a simple sac, and the epithelium lining the outer side is in direct contact with the dense connective tissue of the tunica albuginea (P1. 2, Fig. 3). The connective tissue of the mediastinum testis is not well developed. The majority of the epithelial cells of the rete are small with large karyoplasmic ratios, and they appear structurally similar to the cells lining the transitional tubules. The electron microscope revealed that these cells often contain small amounts of glycogen granules. The minority of epithelial cells are plump columnar or cuboidal in shape, and the cell bodies appear clear and empty in some cells, while others contain glycogen (Pl. 2, Fig. 4). The glycogen varied in density from cell to cell and those that have lost their glycogen appear translucent in the light microscope. In the glycogen-rich cells, the darkly stained nucleus is situated very near the lumen (Pl. 2, Fig. 3) and the other cell organelles are also restricted to the peripheral area of the cytoplasm, probably due to their displacement by the accumulation of glycogen in the cytoplasm. The glycogen-rich cells tend to form a group on the tunica albuginea, and the small epithelial cells are intermingled with the glycogen-rich cells at the periphery of this group.

\section{Ductuli efferentes}

The convoluted tubules of the ductuli efferentes form a mass shortly after leaving the testicular surface, and are firmly attached to the epididymis with connective tissue. At the distal end, they join the epididymal tubule without obvious gross anatomical constriction (Text-fig. 1; Pl. 3, Fig. 7). The lumen of the tubule is widest at the proximal portion and reduces along its length. The epithelium consists of ciliated and non-ciliated cells. The non-ciliated cells have many invaginations in the intermicrovillous region, large vacuoles and numerous lysosomal bodies. In the freeze-fracture images, the tight junctions consist only of a few strands in the apical-basal direction either between two adjacent non-ciliated cells or between non-ciliated and ciliated cells, such strands appearing as a network (P1. 2, Fig. 5) or parallel lines (P1. 2, Fig. 6). Outside the basal lamina, capillaries often penetrate into the thin smooth muscle layer, the cells of which are arranged at right angles to the long axis of the tubule.

\section{Epididymis}

Three portions of the epididymis, the caput, corpus and cauda, are clearly recognizable anatomically (Text-fig. 1; Pl. 1, Fig. 1), with about $12 \mathrm{~mm}$ separating the tip of the caput flexure from that of the caudal flexure. The epithelium lining the epididymis consists of four cell types. The stereo-ciliated principal cells are the predominant cell type (Pl. 4, Figs 9, 11; Pl. 5, Fig. 13), and show some variations along the length of the tubule. The cytological features of the principal cells in different regions of the epididymis are summarized in Table 1. The tight junctions between two adjacent principal cells show a well developed meshwork (P1. 4, Fig. 12). Basal cells with poorly developed organelles are seen throughout the epididymis, and halo cells are occasionally seen. In 
Table 1. The main cytological characteristics of the principal celis in the three different segments of the shrew epididymis

\begin{tabular}{|c|c|c|c|}
\hline Organelles & Initial segment & Middle segment & Terminal segment \\
\hline Stereocilia & Long and irregular & Short and slender & Short and thick \\
\hline Apical vacuoles and multivesicular bodies & + & ++ & \pm \\
\hline Golgi apparatus & ++ & ++ & $+t$ \\
\hline Rough endoplasmic reticulum & ++ & ++ & + \\
\hline Smooth endoplasmic reticulum & \pm & \pm & \pm \\
\hline \multicolumn{4}{|l|}{ Lysosomal bodies } \\
\hline Number & ++ & +++ & ++ \\
\hline Main distribution & Supranuclear zone & Supranuclear zone & Nuclear zone \\
\hline Lipid droplets & - & \pm & - \\
\hline Mitochondria & Rod & Rod $\perp$ & Spherical \\
\hline Nucleus & $\begin{array}{l}\text { Oval with shallow } \\
\text { indentations }\end{array}$ & Bizarre shape & Bizarre shape \\
\hline Glycogen granules & - & - & $\begin{array}{c}- \text { or }+++ \\
\text { (depends on individuals) }\end{array}$ \\
\hline
\end{tabular}

\section{PLATE 1}

Fig. 1. Gross anatomical view of the male reproductive system of the sexually active shrew. Note the terminal swelling (TS) of the ductus deferens just before its junction with the ampulla (A). The thickness of the narrow proximal half of the straight portion of the ductus deferens (labelled DD) is exaggerated by investing connective tissue. T, testis; DD, ductus deferens; UB, urinary bladder; SV, seminal vesicle. All blood vessels are colourless due to perfusion fixation. $\times 3 \cdot 6$.

Fig. 2. The intratesticular excurrent duct system of the shrew. Light micrograph. The terminal portion of the seminiferous tubule (TST) and the rete testis (RT) are connected with a short and tortuous transitional tubule (TT). ST, seminiferous tubule; L, lymphatic vessel; LC, Leydig cells; TA, tunica albuginea. $\times 460$.

\section{PLATE 2}

Fig. 3. Light micrograph showing the epithelial cells lining the rete testis. Note the nuclear position and substance filling the cytoplasm of the epithelial cells sitting on the tunica albuginea (TA). The substance is identifiable as glycogen granules in electron micrographs (see Fig. 4). L, lumen of the rete testis. $\times 610$.

Fig. 4. Electron micrograph showing the glycogen granules in the epithelial cells of the rete testis. $\times 29000$.

Fig. 5. Freeze-fracture electron micrograph. Apical half of the non-ciliated cells of the ductuli efferentes. Note the narrow network of the tight junction formed with the adjacent cell. Various sizes of the vacuoles (V) are seen in the fractured cytoplasm. $\times 25000$.

Fig. 6. Freeze-fracture image. Tight junction of the adjacent non-ciliated cells of the ductuli efferentes. It consists of only two discontinuous parallel strands. P, P face; E, E face. $\times 118000$.

\section{PLATE 3}

Figs $7 \&$ 8. Low magnification light microscopical view of the caput (Fig. 7) and the cauda (Fig. 8) epididymidis of the shrew. In Fig. 7, the apex of the caput flexure is located on the right side. Connective tissue septa are not conspicuous. The borders of ductuli efferentes (DE), initial segment (IS) and middle segment (MS) are demarcated with broken lines. Note the small number of spermatozoa in the initial segment. In Fig. 8, the apex of the caudal flexure is located on the left side. Note the large number of spermatozoa in the wide lumen of the terminal segment (TS) of the epididymis. The proximal part of the ductus deferens (pars epididymica, $\mathrm{PE}$ ) has a smaller luminal diameter and thicker smooth muscular layer than those of the terminal segment (TS) of the epididymis. Fig. 7, $\times 92$; Fig. 8, $\times 110$. 


\section{PLATE 1}
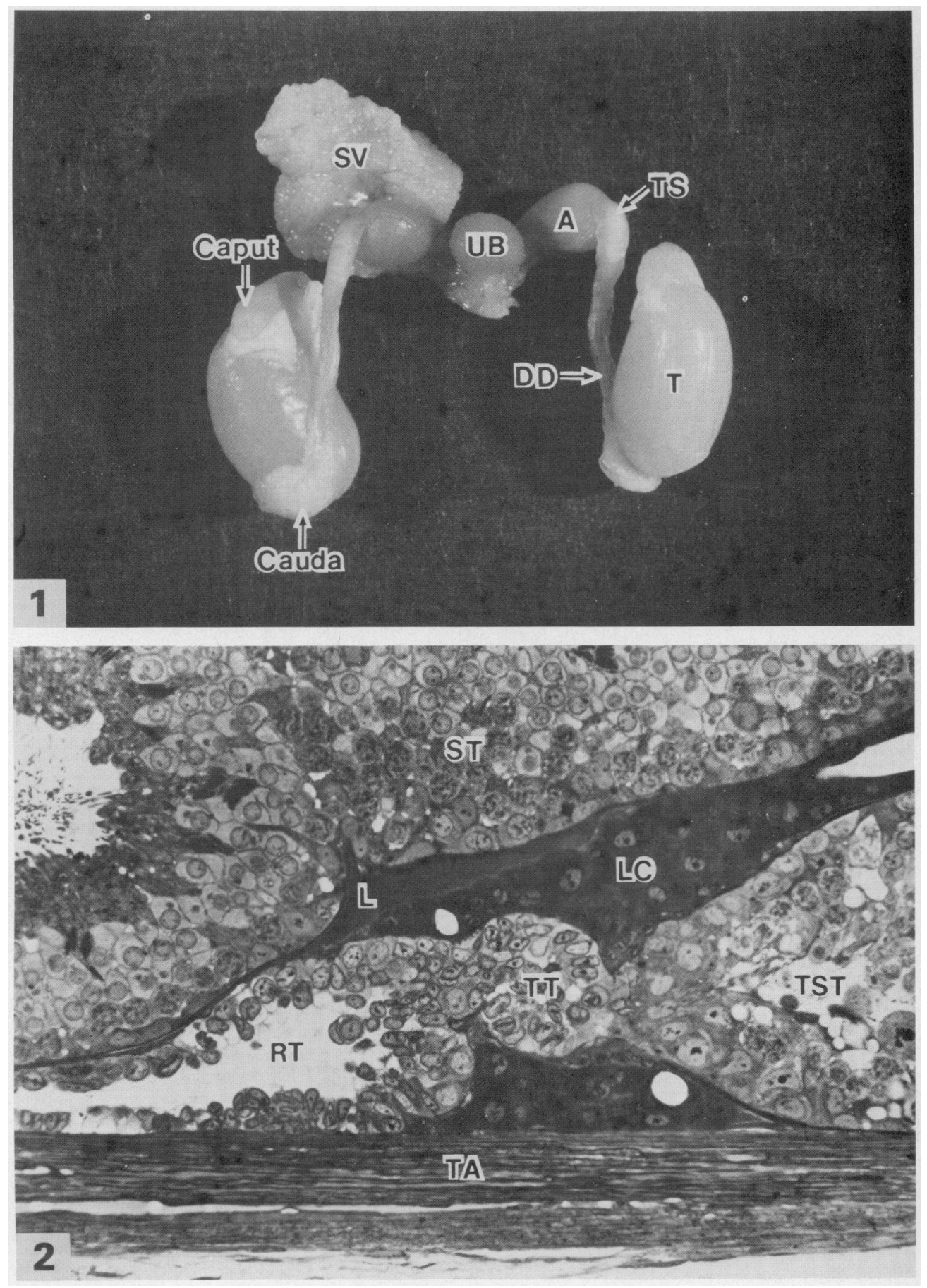


\section{PLATE 2}
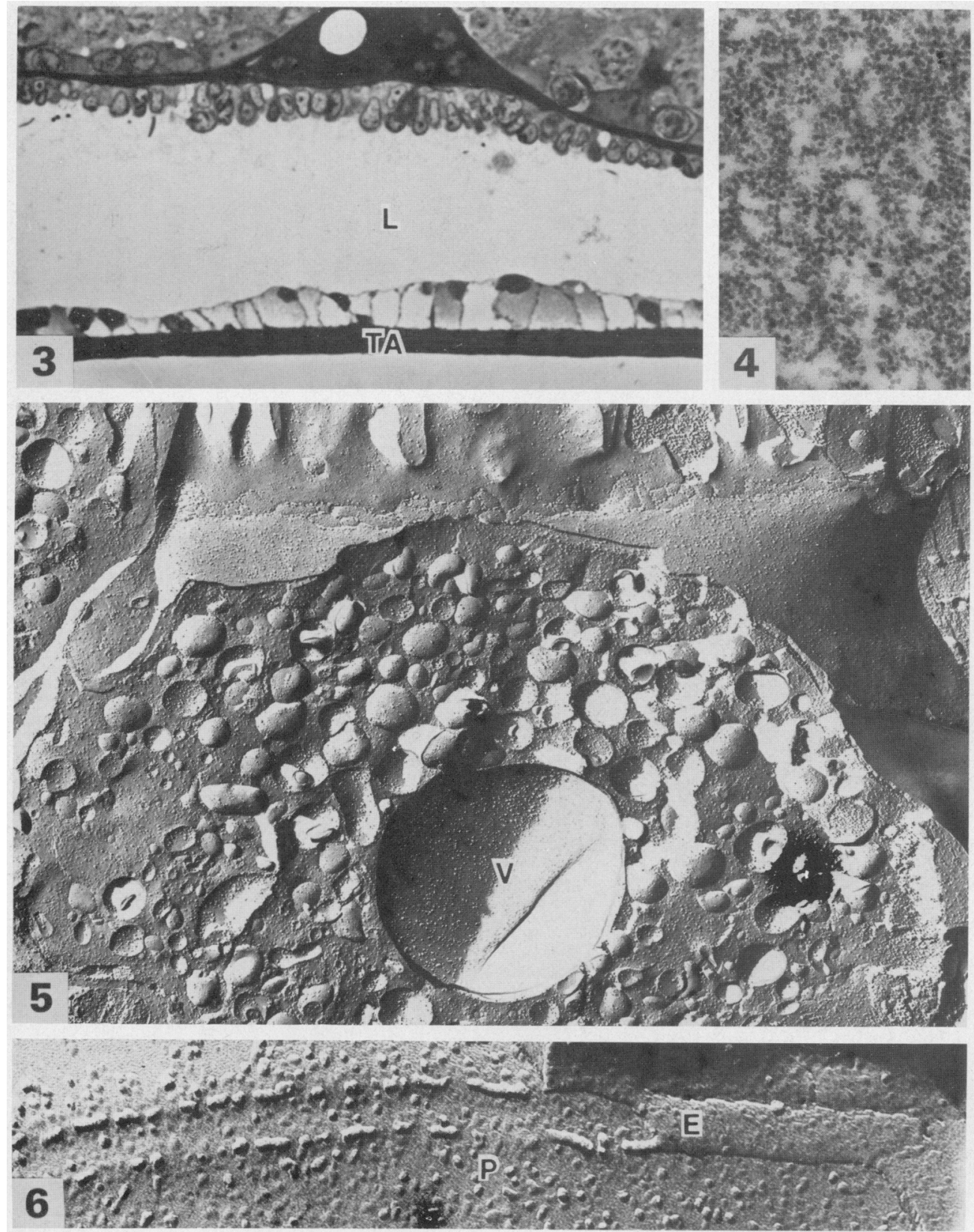
PLATE 3
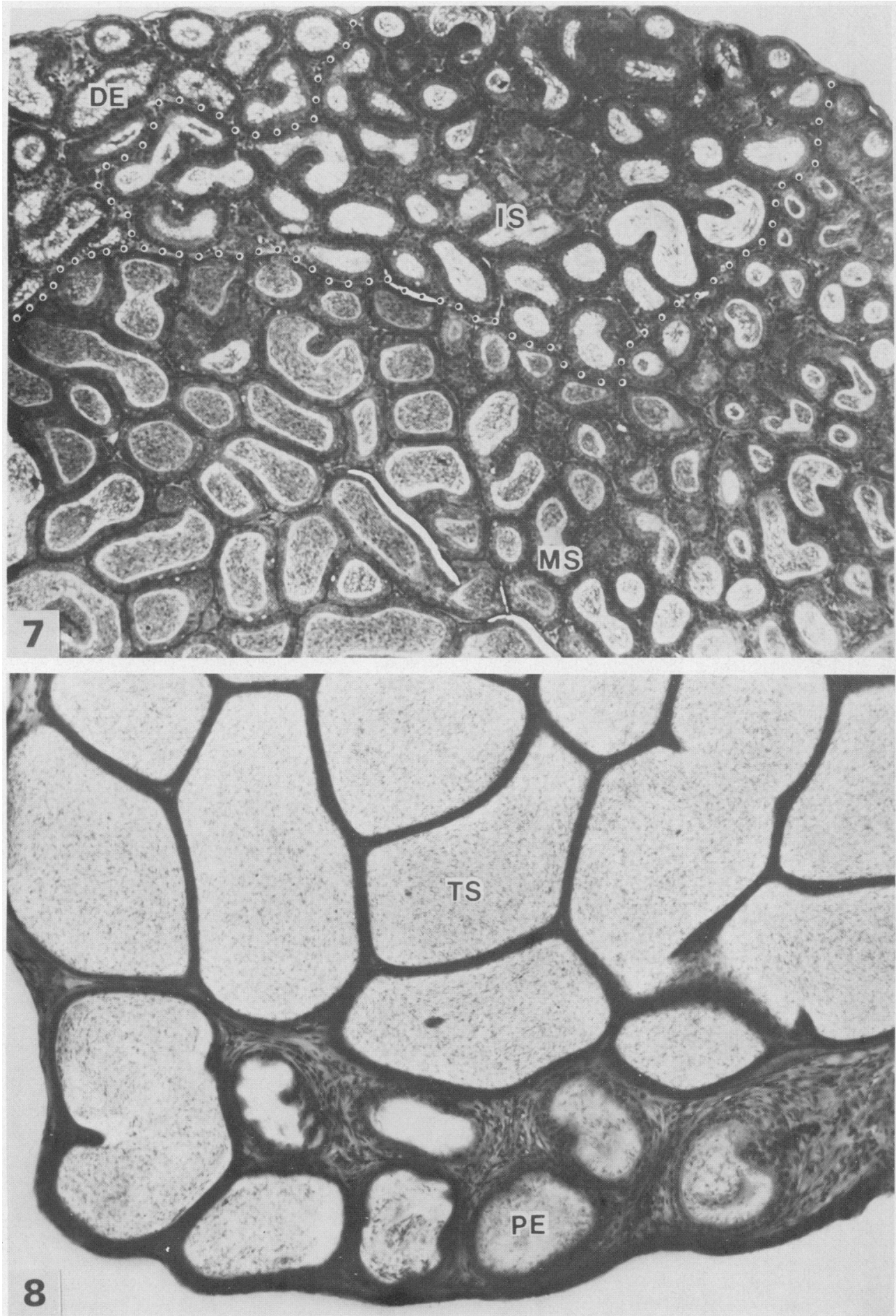
PLATE 4
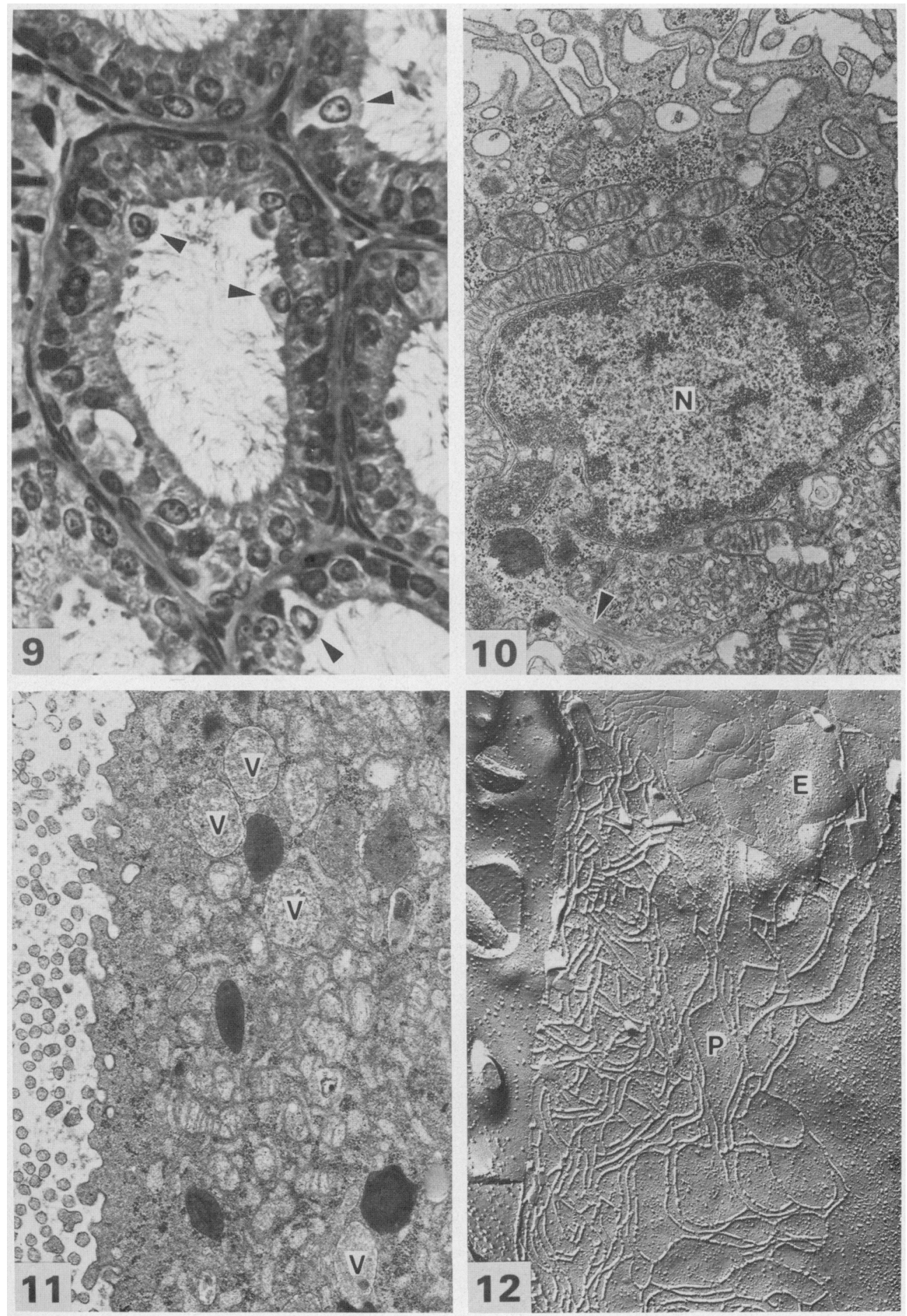


\section{PLATE 5}

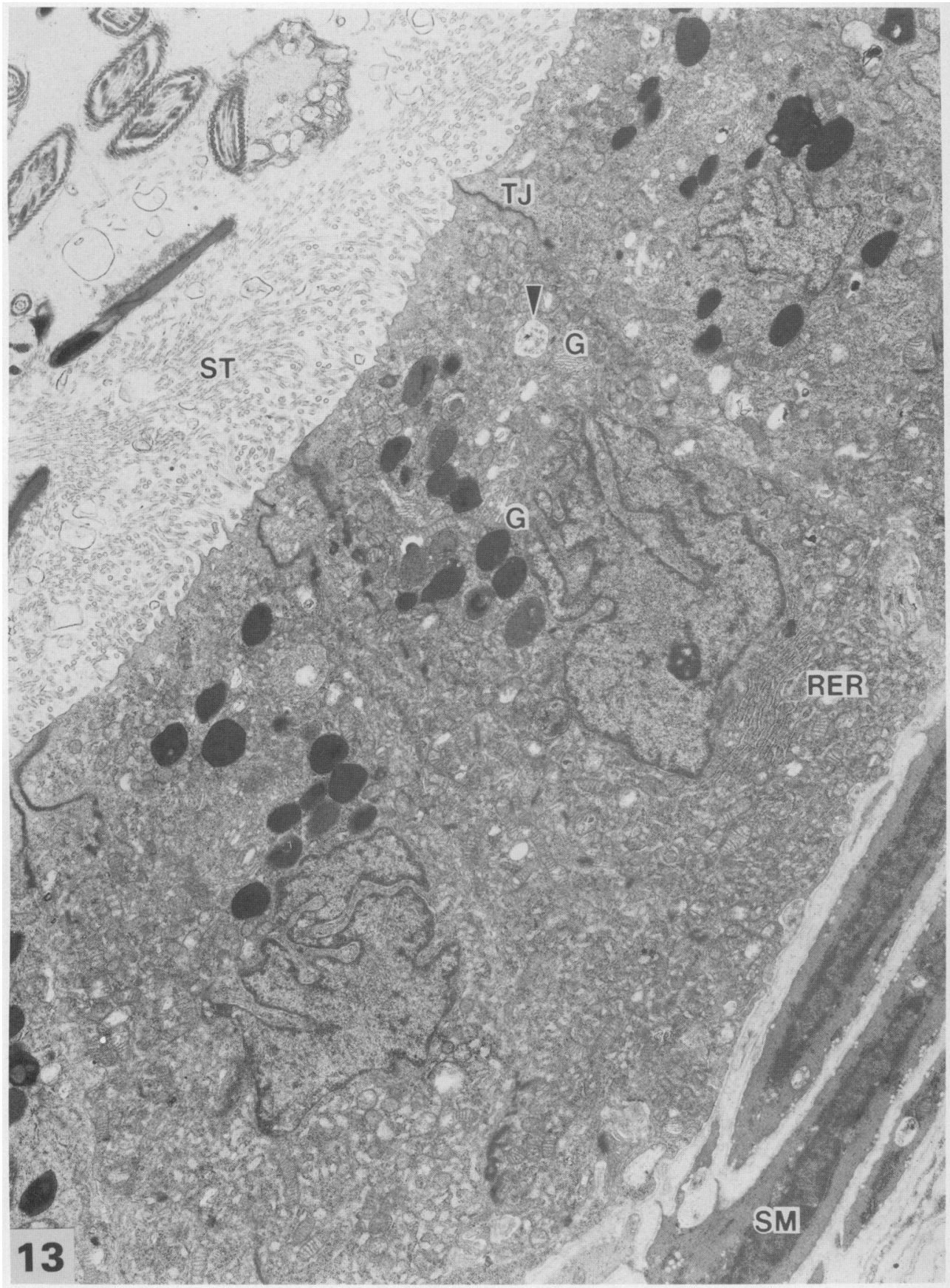


PLATE 6
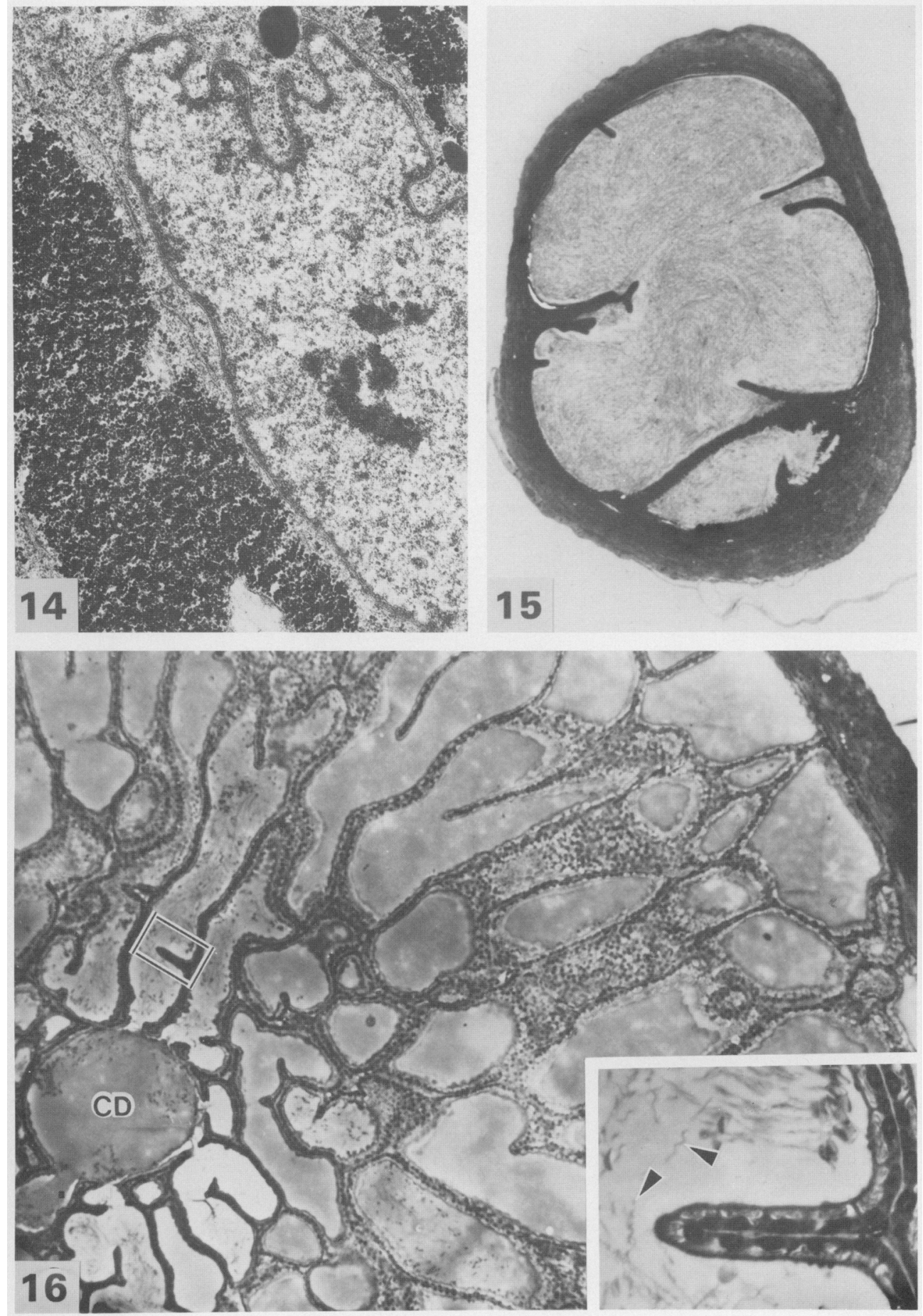
the initial segment and the most proximal part of the middle segment, another cell type was evident. In the light microscope, it is easily distinguished from the adjacent principal cells by its clear cytoplasm (Pl. 4, Fig. 9). It often protrudes toward the lumen and reaches the basal lamina with a slender basal portion. The nucleus with, generally, one nucleolus is situated in the apical cytoplasm. In the electron microscope, the most striking structural feature of this cell is the large number of mitochondria in the apical cytoplasm and around the nucleus (P1. 4, Fig. 10) and the cell will thus be referred to as the 'mitochondrion-rich cell'. Bundles of filaments are apparent in the cytoplasm together with a small number of lysosomal bodies. Deep invaginations and vacuoles can be seen in the apical cytoplasm in some cells and the microvilli are much shorter than in adjacent principal cells. The Golgi apparatus and endoplasmic reticulum are poorly developed.

Immediately surrounding the basal lamina of the epididymal tubule, from the initial segment to the terminal segment are 2-3 layers of thin smooth muscle (PI. 4, Fig. 9; Pl. 5, Fig. 13). The convoluted tubule of the epididymis is tightly packed, and very little connective tissue fills the space between the tubules. The dense connective tissue septa are also poorly developed, and the segmentation of the epididymis is thus obscure (Pl. 3, Figs $7 \& 8$ ).

The tubular and the luminal diameter of 5 representative portions (see Text-fig. 1, I-V) are shown in Text-fig. 2, together with the epithelial cell height. When the morphological criteria of Glover \& Nicander (1971) are applied to the shrew epididymis, regions I, II-IV, and V correspond with the initial, the middle and the terminal segments respectively. The lumen of the initial segment has a round profile in cross-section and contains electron-permeable fluid and few spermatozoa. The epithelial height is $14.2 \pm 2.4 \mu \mathrm{m}$ (s.d.) and is very similar to that of the ductuli efferentes and the middle segment (P1. 3, Fig. 7). In the middle segment, the lumen is packed with

\section{PLATE 4}

Fig. 9. Light micrograph of the initial segment. Mitochondrion-rich cells (arrowheads) are seen among the principal cells with long and tortuous stereocilia. $\times 590$.

Fig. 10. Electron micrograph of the apical portion of a mitochondrion-rich cell. Note the many mitochondria with lamellar cristae. Invaginations of the luminal surface and vacuoles may suggest pinocytic activity of this cell. An arrowhead indicates a bundle of filaments. N, nucleus. $\times 15800$.

Fig. 11. Apical part of a principal cell in the caput epididymidis (at III in Text-fig. 1). Apical invaginations, small vesicles, vacuoles (V) and some lysosomal bodies are seen. $\times 13000$.

Fig. 12. Freeze-fracture image of the tight junction of the epididymal epithelium at III in Textfig. 1. Note the well developed meshworks of the strands. P, P face; E, E face. $\times 41000$.

\section{PLATE 5}

Fig. 13. Electron micrograph of the principal cells of the corpus epididymidis (at IV in Textfig. 1). Many lysosomal bodies are seen mainly in the apical cytoplasm. One multivesicular body is indicated by an arrowhead. ST, stereocilia; TJ, tight junction; G, Golgi apparatus; RER, rough endoplasmic reticulum; SM, smooth muscle. $\times 7200$.

\section{PLATE 6}

Fig. 14. Electron micrograph of the principal cell of the cauda epididymidis (at V in Text-fig. 1). Masses of glycogen granules are seen around the nucleus. $\times 17300$.

Fig. 15. Cross-section of the terminal swelling of the ductus deferens. The wide lumen is packed with spermatozoa. The epithelium shows several foldings into the lumen. $\times 64$.

Fig. 16. Cross-section of the ampulla. Many glands are arranged radially around the central duct (CD). Spermatozoa are present in several lumina of the glands. Thick smooth muscle layers can be seen at the upper right corner. The area marked by the rectangle in the main figure is enlarged as inset, in which epithelial cells with large Golgi apparatus and spermatozoa with wavy tails (arrowheads) are seen. $\times 90$ (inset $\times 550$ ). 


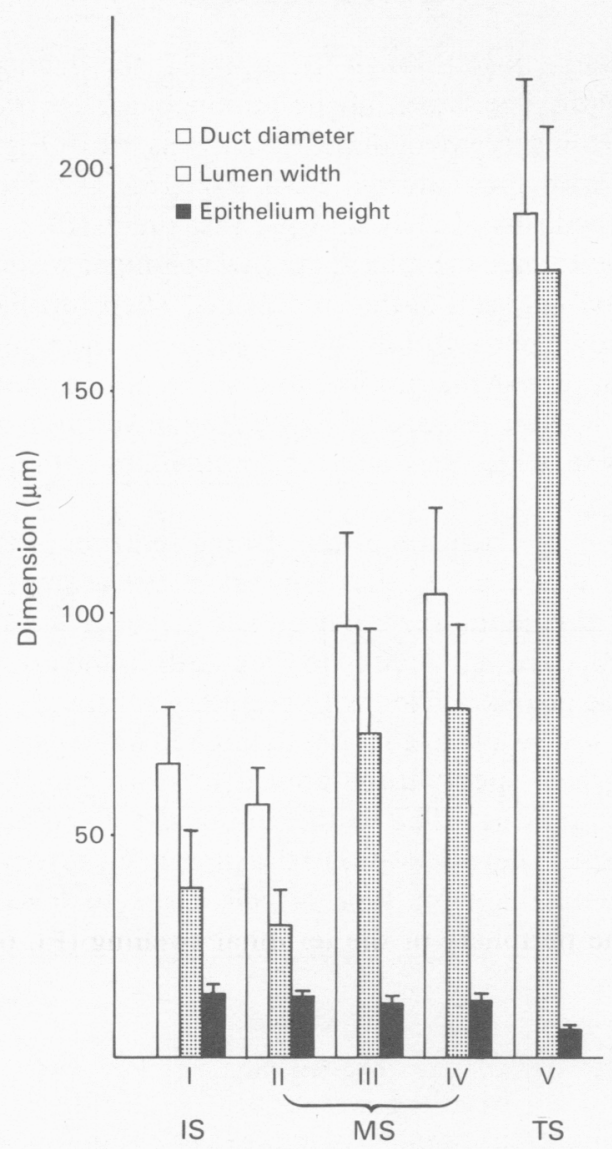

Text-fig. 2. The diagram shows the diameters of the duct, the width of the lumen and the height of the epithelium in 5 different regions of the epididymal duct. I-V correspond with the positions shown in Text-fig. 1. Bars on each column represent standard deviations $(n=30)$. IS, initial segment; MS, middle segment; TS, terminal segment.

spermatozoa suspended in an amorphous substance. In the proximal part of this segment, the lumen is narrowest, but it increases distally. The principal cells of this segment contain absorbing vacuoles of about $0.8 \mu \mathrm{m}$ in diameter, which in some cases themselves contain vesicles (Pl. 5, Fig. 13). The vacuoles are more common in the proximal part of the middle segment (Pl. 4, Fig. 11). In the terminal segment, the wide lumen is filled with spermatozoa (Pl. 3, Fig. 8) although their density is lower than in the middle segment. The height of the lining epithelium is $6.2 \pm 1.1 \mu \mathrm{m}$ (s.d.) and is only about half as tall as that in the more proximal segments (Text-fig. 2). The smooth muscle layers remain thin even at the caudal flexure. In some individuals, large glycogen granules are found around the nucleus of the principal cells (PI. 6, Fig. 14).

\section{Ductus deferens}

The ductus deferens is about $16 \mathrm{~mm}$ long. It is grossly subdivided into three different regions. The proximal part is the epididymal portion of the ductus deferens (pars epididymica), where the duct is is still tortuous (Pl. 3, Fig. 8). The straight middle portion is slender at the proximal half and gradually widens in the distal half (Text-fig. 1; Pl. 1, Fig. 1). It then constricts slightly before it joins the conspicuous ampulla, which gradually tapers distally to its junction with the urethra (Text-fig. 1; Pl. 1, Fig. 1). 
With the exception of its passage through the ampulla, the ductus deferens shows a similar structure throughout its length. The lumen of the proximal part of the ductus deferens is much narrower than that of the terminal segment of the epididymis (Pl. 3, Fig. 8), and the wide lumen of the distal half is distended with spermatozoa (P1. 6, Fig. 15). The ductus deferens is lined by a pseudostratified epithelium with basal cells showing infoldings (Pl. 6, Fig. 15). In the proximal portion, the principal cells with pale cytoplasm are low columnar in shape, and about double the height of those in the terminal segment of the epididymis. Their tuft-like stereocilia are very long and thick. In the straight middle portion of the ductus deferens, the principal cells are squamous or cuboidal in shape, and their stereocilia are fine and short. The smooth muscle layer exhibits a proximodistal increase in thickness (Pl. 3, Fig. 8), due to the addition of the large smooth muscle cells to the thin smooth muscle, which surrounds the epithelium both in the ductuli efferentes and epididymis.

The duct, which is the direct extension of the straight portion of the ductus deferens, passes through the long axis of the ampulla and thus appears in the centre of the cross section. Many glands are arranged radially around this central duct, and give it an alveolar appearance (P1. 6, Fig. 16). The glands are branched and open directly to the lumen of the central duct without excurrent ducts. The wide lumen of the glands is filled with secretory substance. Spermatozoa were seen in some lumina, and their tails were wavy in contrast to those in more proximal parts of the excurrent duct (Pl. 6, Fig. 16, inset). Such spermatozoa appear to stray into the gland, because they are commonly seen near the central duct. The epithelium of the gland consists of only one type of cuboidal cell, which has a large Golgi apparatus in the supranuclear zone (P1. 6, Fig. 16, inset). The central duct is also lined with the same type of cell. Over 10 layers of smooth muscle cells surrounded the glands at the periphery of the terminal swelling (P1. 6, Fig. 16).

\section{Discussion}

Towards the ends of the seminiferous tubules, in many of the mammalian species examined, there is a gradual depletion of germ cells and the short terminal segment is lined only by Sertoli cells or modified Sertoli cells (Dym, 1974; Wrobel, Sinowatz \& Mademann, 1982). There is then an abrupt transition from the Sertoli cell epithelium to the simple cuboidal or columnar epithelium of the tubuli recti (Dym, 1974, 1976). This was confirmed in the present study in the shrew, although the transition tubule (equivalent to the tubuli recti) is not straight.

The mammalian rete testis can be classified into two types, superficial and axial, according to the gross anatomy. The rete testis of the shrew is superficial, like that of the rat (Roosen-Runge, 1961 ; Dym, 1976) and the presence of glycogen-rich cells in the epithelium is remarkable in this species. Such conspicuous glycogen storage in the epithelium lining the distal segment of the tubuli recti and neighbouring portions of the rete testis has been reported only in the guinea-pig by Fawcett \& Dym (1974), who demonstrated the extraordinary concentration of glycogen granules by the use of ferrocyanide-reduced osmium textroxide after glutaraldehyde fixation. Although glycogen is less well preserved in our conventionally fixed specimens, sufficient remained for its identity to be confirmed in the electron microscope. Since the topographical characteristics of the glycogen-rich cells, such as a plump columnar form, juxtaluminal position of the nucleus and the presence of cell organelles in the peripheral cytoplasm, are similar to those of the guinea-pig (Fawcett \& Dym, 1974), there is little doubt that glycogen is densely packed in vivo in the shrew. Although the functional significance of such large amounts of glycogen is unknown, the present observation provides another example of glycogen-rich cells in the excurrent duct system of mammals. In the shrew, however, the glycogen-rich cells are restricted to the rete testis and are not found in the tubuli recti.

The absorptive function of the proximal part of the excurrent duct is well known (Crabo, 1965). The route of absorption of testicular fluid has been established by following the uptake of vital dyes 
(Montorzi \& Burgos, 1967): the canalicular invaginations, the vacuoles and lysosomal bodies provide the machinery for absorption, and were also found in the shrew. The intercellular pathway for fluid absorption may also exist in the ductuli efferentes, since tight junctions between epithelial cells are poorly developed in many mammalian species examined (Suzuki \& Nagano, 1978; Nagano \& Suzuki, 1980). The present study shows that the tight junctions of the shrew are also poorly developed in the ductuli efferentes, but unlike those of rats (Suzuki \& Nagano, 1978), mice, guinea-pigs or man (Nagano \& Suzuki, 1980), they are not associated with belt-like gap junctions. The presence of fenestrations in the capillary endothelium has been demonstrated in the guinea-pig (Ladman \& Young, 1958) and in the mouse (Suzuki, 1982), where they may form part of a fluid drainage system. Although the capillary endothelium of the shrew is continuous, the capillaries penetrate into the smooth muscle layer, and may fulfil a similar function.

The epididymal duct shows functional and histological variations along its length, and its zonation has been reported in many mammals including the rabbit (Nicander, 1957), stallion, bull, ram (Nicander, 1958) and rat (Reid \& Cleland, 1957). Although variations preclude exact correspondence of the segments between different species, the first part of the epididymal duct has features common to many mammals, and Benoit (1926) called this part the initial segment. Glover \& Nicander (1971) included the middle and terminal segments in addition to the initial segment in their general terminology of the mammalian epididymis. In many mammals the initial segment is clearly demarcated by connective tissue septa, but in the shrew epididymis septa are poorly developed and segmentation is not clear. Nevertheless, the initial segment of the shrew epididymis has some histological characteristics common to those of other mammals, such as a low density of luminal spermatozoa and long stereocilia, but differs from the standard description by Glover \& Nicander (1971) in that the epithelial height is not conspicuously greater than that of the ductuli efferentes and the middle segment. In the middle segment of the shrew epididymis, the luminal spermatozoa are more concentrated, as in other mammals (Glover \& Nicander, 1971), and the vacuoles that characterize the principal cells of this segment are commonly seen, particularly in the proximal part of this segment. They are, however, smaller in size than those of the hamster (Nicander \& Glover, 1973), the rabbit (Jones, Hamilton \& Fawcett, 1979; Nicander \& Plöen, 1979), the mole (Suzuki \& Racey, 1976). The wide lumen and the low epithelial height and virtual absence of large vacuoles in the terminal segment of the shrew epididymis are features common to this segment in other mammals (Nicander \& Glover, 1973; Nicander \& Plöen, 1979). However, in the shrew, the smooth muscle investment does not show a proximodistal increase in thickness before the caudal flexure, and the large smooth muscle cells, which are added to the small smooth muscle-like cells at the transition from the corpus to the cauda in more advanced mammals (Baumgarten, Holstein \& Rosengren, 1971), appear distal to the caudal flexure in the shrew. Morphologically, the cauda epididymidis appears to function as a sperm reservoir in the shrew, but the spermatozoa in this reservoir may not be used at the time of ejaculation, since the smooth muscle cells, which are responsible for the expulsion of spermatozoa during ejaculation (Baumgarten et al., 1971), are absent from this portion. The cytological differences of the principal cells between the epididymal regions are also not as clear in the shrew as they are in some other mammals. Neither the lipid-rich zone seen in moles (Suzuki \& Racey, 1976), guinea-pigs (Hoffer \& Karnovsky, 1981) and rabbits (Jones et al., 1979) nor the zone rich in smooth endoplasmic reticulum seen in rabbits (Jones et al., 1979) are observed in the shrew epididymis. As a whole, although the three segments proposed by Glover \& Nicander (1971) are fundamentally recognizable in the shrew epididymis, the regional variations are less conspicuous when compared with those in other insectivores, such as the mole (Suzuki \& Racey, 1976).

In the juxtaluminal position of the nucleus, the short microvilli, and the presence of apical vacuoles, the mitochondrion-rich cell of the shrew epididymis resembles the narrow cells of the initial segment of the adult rat epididymis (Sun \& Flickinger, 1980). Similar mitochondrion-rich cells have been reported in the human ductus deferens (Hoffer, 1976), and in the monkey epididymis (Ramos \& Dym, 1977). Cohen, Hoffer \& Rosen (1976) have demonstrated carbonic anhydrase activity in cells with apical nuclei in the initial segment and zone 2 of the rat caput 
epididymidis, and in the clear cells of the more distal regions, and have suggested that these cells might be involved in the process of acidification and alkalinization that occurs along the length of the duct. However, it has been pointed out subsequently that the cells with apical nuclei correspond to the narrow cells described by Sun \& Flickinger (1980) as containing numerous mitochondria, rather than to the apical cells described by Reid \& Cleland (1957).

Glover \& Nicander (1971) include the proximal convoluted portion of the gross anatomical ductus deferens of scrotal mammals in the terminal segment of the epididymis. However, the tall columnar principal cells described in the ductus deferens of the human (Hoffer, 1976), rat (Hamilton \& Cooper, 1978), and monkey (Ramos, 1979) are absent from the shrew. Moreover, the principal cells of the straight middle portion of the shrew ductus deferens show some cytological characteristics common to the terminal segment of the epididymis. These observations support the view that the whole length of the gross anatomical ductus deferens of the shrew should be included in the terminal segment of the epididymis. However, we prefer to refer to these regions as 'ductus deferens', because some cytological features of the principal cells of the proximal convoluted portion, such as long and thick stereocilia, deviate from the criteria suggested by Glover \& Nicander (1971), and the musculature is much like that of the ductus deferens of scrotal mammals.

The present observations on the shrew suggest that the distal half of the straight portion of the ductus deferens as well as the cauda epididymidis functions as a sperm reservoir. It is interesting to consider these two separate sites of sperm storage in the Wolffian duct in relation to the position of the testes, which are located in shallow pouch-like extensions of the posterior end of the abdominal cavity (Pearson, 1944). Glover \& Sale (1968), Glover \& Nicander (1971) and Glover (1973) pointed out that the sperm reservoir is located at the distal pole of the testis in scrotal mammals, but in testicond mammals the homologous area is located in the pelvic cavity while the testes are situated immediately caudal to the kidneys (Text-fig. 3). In this respect, the shrew exhibits an intermediate position between the testicond and the scrotal mammals, with sperm reservoirs located both at the distal pole of the testis and just proximal to the ampulla.
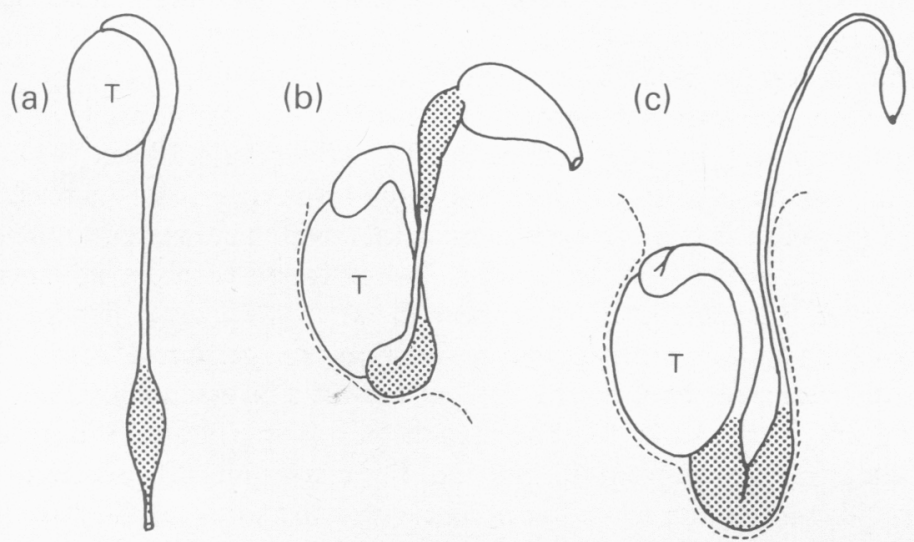

Text-fig. 3. A diagrammatic representation of the sites of sperm storage (dotted areas) in relation to the testicular position. (a) Hyrax as an example of a testicond mammal; (b) shrew; (c) rabbit as an example of a scrotal mammal. Broken lines in (b) and (c) represent the body surface. $T$, testis.

The microscopical appearance of the accessory gland of reproduction situated between the terminal swelling of the ductus deferens and the urethra in the shrew Sorex araneus in this study corresponds well with the description and line-drawing by Ärnbäck-Christie-Linde (1907) for $S$. vulgaris $(=S$. araneus $)$. The glandular appearance is similar to that of the ampulla of the monkey (Ramos, 1979), although the lumen of the central duct of the terminal swelling is narrower than that of the ampulla of ruminants or primates. Ärnbäck-Christie-Linde (1907) referred to this structure as an ampulla and its position and structure are consistent with such nomenclature (Mann, 1964). 
The work is supported by a grant from the Japanese Ministry of Education, Culture and Science. We thank Professor T. Nagano for encouragement and criticism, and Dr A. Hardy and Dr J. B. Searle for providing some of the shrews.

\section{References}

Ärnbäck-Christie-Linde, A. (1907) Der Bau der Soriciden und ihre Beziehungen zu andern Saugetieren. Morph. Jb. 36, 463-514.

Baumgarten, H.H., Holstein, A.F. \& Rosengren, E. (1971) Arrangement, ultrastructure, and adrenergic innervation of smooth musculature of the ductuli efferentes, ductus epididymidis and ductus deferens of man. Z. Zellforsch. mikrosk. Anat. 120, 37-79.

Benoit, J. (1926) Recherches anatomiques, cytologiques et histophysiologiques, sur les voies excrétrices du testicules chez les mammifères. Archs Anat. Histol. Embryol. 5, 173-412.

Brambell, F.W.R. (1935) Reproduction in the common shrew (Sorex araneus Linnaeus). II. Seasonal changes in the reproductive organs of the male. Phil. Trans. $R$. Soc. $B$ 225, 51-62.

Cohen, J.P., Hoffer, A.P. \& Rosen, S. (1976) Carbonic anhydrase localization in the epididymis and testis of the rat: histochemical and biochemical analysis. Biol. Reprod. 14, 339-346.

Crabo, B. (1965) Studies on the composition of epididymal content in bulls and boars. Acta vet. scand., Suppl. 5, 1-94.

Dym, M. (1974) The fine structure of monkey Sertoli cells in the transitional zone at the junction of the seminiferous tubules with the tubuli recti. Am. J. Anat. 140, 1-26.

Dym, M. (1976) The mammalian rete testis-a morphological examination. Anat. Rec. 186, 493-524.

Eisenberg, J.F. (1981) The Mammalian Radiations. Athlone, London.

Fawcett, D.W. \& Dym, M. (1974) A glycogen-rich segment of the tubuli recti and proximal portion of the rete testis in the guinea-pig. J. Reprod. Fert. 38, 401-409.

Glover, T.D. (1973) Aspects of sperm production in some East African mammals. J. Reprod. Fert. 35, 45-53.

Glover, T.D. \& Nicander, L. (1971) Some aspects of structure and function in the mammalian epididymis. J. Reprod. Fert., Suppl. 13, 39-50.

Glover, T.D. \& Sale, J.B. (1968) The reproductive system of male rock hyrax (Procavia and Heterohyrax). $J$. Zool., Lond. 156, 351-362.

Hamilton, D.W. \& Cooper, T.G. (1978) Gross and histological variations along the length of the rat vas deferens. Anat. Rec. 190, 795-810.

Hoffer, A.P. (1976) The ultrastructure of the ductus deferens in man. Biol. Reprod. 14, 425-443.

Hoffer, A.P. \& Kamovsky, M.L. (1981) Studies on zonation in the epididymis of the guinea pig. I. Ultrastructural and biochemical analysis of the zone rich in large lipid droplets (Zone II). Anat. Rec. 201, 623-633.

Jones, R., Hamilton, D.W. \& Fawcett, D.W. (1979) Morphology of the epithelium of the extratesticular rete testis, ductuli efferentes and ductus epididymidis of the adult male rabbit. Am. J. Anat. 156, 373-400.
Ladman, A.J. \& Young, W.C. (1958) An electron microscopic study of the ductuli efferentes and rete testis of the guinea pig. J. Biophys. Biochem. Cytol. 4, 219-226.

Mann, T. (1964) The Biochemistry of Semen and of the Male Reproductive Tract. Methuen, London.

Montorzi, N.M. \& Burgos, M.H. (1967) Uptake of colloidal particles by cells of the ductuli efferentes of the hamster. Z. Zellforsch. mikrosk. Anat. 83, 58-69.

Nagano, T. \& Suzuki, F. (1980) Belt-like gap junctions in the ductuli efferentes of some mammalian testes. Archs Histol. Jpn 43, 185-189.

Nicander, L. (1957) On the regional histology and cytochemistry of the ductus epididymidis in rabbits. Acta morph. neerl. scand. 1, 99-118.

Nicander, L. (1958) Studies on the regional histology and cytochemistry of the ductus epididymidis in stallions, rams and bulls. Acta morph. neerl. scand. 1, 337-362.

Nicander, L. \& Glover, T.D. (1973) Regional history and fine structure of the epididymal duct in the golden hamster (Mesocricetus auratus). J. Anat. 114, 347364.

Nicander, L. \& Plöen, L. (1979) Studies on regional fine structure and function in the rabbit epididymis. Int. J. Androl. 2, 463-481.

Pearson, O.P. (1944) Reproduction in the shrew (Blarina brevicauda Say). Am. J. Anat. 75, 39-93.

Ramos, A.S., Jr (1979) Morphologic variations along the length of the monkey vas deferens. Archs Androl. 3, 187-196.

Ramos, A.S., Jr \& Dym, M. (1977) Fine structure of the monkey epididymis. Am. J. Anat. 149, 501-532.

Reid, B.L. \& Cleland, K.W. (1957) The structure and function of the epididymis. I. The histology of the rat epididymis. Aust. J. Zool. 5, 223-246.

Roosen-Runge, E.C. (1961) The rete testis in the albino rat: its structure, development and morphological significance. Acta anat. 45, 1-30.

Sun, E.L. \& Flickinger, C.J. (1980) Morphological characteristics of cells with apical nuclei in the initial segment of the adult rat epididymis. Anat. Rec. 196, 285-293.

Suzuki, F. (1982) Microvasculature of the mouse testis and excurrent duct system. Am. J. Anat. 163, 309325.

Suzuki, F. \& Nagano, T. (1978) Regional differentiation of cell junctions in the excurrent duct epithelium of the rat testis as revealed by freeze-fracture. Anat. Rec. 191, 503-520.

Suzuki, F. \& Racey, P.A. (1976) Fine structural changes in the epididymal epithelium of moles (Talpa europaea) throughout the year. J. Reprod. Fert. 47, 47-54.

Wrobel, K.-H., Sinowatz, F. \& Mademann, R. (1982) The fine structure of the terminal segment of the bovine seminiferous tubule. Cell Tiss. Res. 225, 29-44.

Received 1 June 1983 